\title{
MARIJAN PAVČNIK, AUF DEM WEG ZUM MASS DES RECHTS . AUSGEWÄHLTE SCHRIFTEN ZUR RECHTSTHEORIE, STUTTGART, FRANZ STEINER VERLAG, 2011. - PRIKAZ KNJIGE
}

Pred nama je djelo poznatog slovenskog profesora teorije i filozofije prava na Pravnom fakultetu Sveučilišta u Ljubljani, koje predstavlja zbornik već objavljenih radova, publiciranih u raznim časopisima i publikacijama, krajem prošlog i početkom ovoga stoljeća.

Zbornik sadrži ukupno 14 priloga, koji su reproducirani - prema izvornim izdanjima - na njemačkom i engleskom jeziku. Kako sam autor navodi u predgovoru, njegova su razmišljanja usredotočena na pitanje kako pravo treba razumjeti i posebno kako razjasniti problem razmjernosti u pravu. Uz tu opću poveznicu, svaki od priloga može se promatrati i kao cjelina za sebe, odnosno kao niz rasprava o ključnim temama teorije prava. O tim i drugim pitanjima teorije prava, autor je već dao znatan doprinos u svojim dvjema važnim publikacijama: u knjizi Argumentocija v pravu (2. izdanje, 2004.) i u djelu Teorija prava, koje je doživjelo već treće izdanje 2007. godine.

Prilozi u knjizi sistematizirani su u šest odjeljaka sa sljedećim podnaslovima: I. Pravično uračunavanje kao jezgro prava II. Održivost prava i pravne države III. Odgovorno pravno odlučivanje IV. Korelativnost prava V. Dijaloška priroda jurisprudencije i VI. Iz slovenske misaone baštine.

Na početku se nalazi rad "Die Rechtsnorm” (izvorno objavljen u časopisu Archiv f. Rechtu. Soziolphilosophie, 1997.). U njemu se razlaže pojam pravne norme kroz sve njezine bitne dimenzije: kognitivnu, jezičnu - akcijsku, komunikacijsku i metajuridičku (teorijsku). Autor se naročito usredotočuje na tipologiju normi, ukazujući na bitne karakteristike općih, apstraktnih te konkretnih i pojedinačnih normi. On također ističe zapažanje - koje je opće prihvaćeno u pravno-teorijskoj literaturi - da pravna norma nije identična sa zakonskim člancima, odnosno s njezinim jezičnim oblicima (njem. Rechtssatz), nego se sastoji u značenju, koje se zadobiva u njezinu tumačenju, odnosno u metajeziku, koji pripada u područje razumijevanja i primjene pravnih akata.

U drugom radu pod naslovom: "Bruchigkeit der Gerechtigkeit" (Krhkost pravednosti), autor ukazuje na postojeće kriterije za utvrđivanje pravednosti pravnog odlučivanja. Tako se susreću različite formule i mjerila za donošenje odluka u skladu s pravednošću: od rimskog načela suum cuique... do formalnog zahtjeva da se jednake tretira jednako. Unatoč pokušajima da se

Dr. sc. Duško Vrban, umirovljeni izvanredni profesor Pravnog fakulteta Sveučilišta Josipa Jurja Strossmayera u Osijeku. Prebivalište: Jože Gabrovšeka 5, 51000 Rijeka, Republika Hrvatska. Adresa e-pošte: dusko.vrban@gmail.com. ORCID: https:// orcid.org/0000-0002-5621-2067 
pronađe zadovoljavajuća opća formula pravednosti, postojeći kriteriji - među koje u moderno doba pripada i sloboda, mir, demokracija i tolerancija - ne mogu biti adekvatni ako se ne vodi računa o ljudskom čimbeniku, osjećaju za pravednost, što su već istaknuli Perelman i Pitamic.

Sljedeća tri rada bave se problemom tranzicije i argumentom o "nepravu" kao podlozi za reviziju prijašnjeg socijalističkog zakonodavstva, odnosno kao osnove za raspravu i ispravljanje nepravde komunističkih režima u istočnoj Europi. Autor ističe da se argument o "nepravu" ne može braniti s gledišta pravnog pozitivizma, nego se upravo na tome stjecištu uočava nedostatak takvog načina razmišljanja koji ne sagledava pravni fenomen izvan granica pozitivnog zakonodavstva.

Moglo bi se reći da je glavna preokupacija autora odrediti koja mjerila pridonose da se pravo u primjeni što prihvatljivije odrediti prema zahtjevima djelotvornosti i pravičnosti. Naime, pravo nije relevantno ako se ne odredi prema društveno prihvaćenim i legitimnim vrijednostima. Jedna je od tih vrijednosti i pravednost koja se u pravničkoj praksi sažima u konceptu pravičnosti. Međutim, pravo je ponajprije i djelatnost koja zadovoljava praktične potrebe društva te je način razmišljanja i odlučivanja praktičnog pravnika od prvorazredne važnosti. 